\title{
Depositional sequences and sequence boundaries in fore-arc coastal embayments: case histories from Central America
}

\author{
HANNELORE SCHMIDT and HARTMUT SEYFRIED \\ Institut für Geologie und Paläontologie, Universität Stuttgart, Böblinger Strasse 72, D 7000 Stuttgart l, \\ Germany
}

\begin{abstract}
From Oligocene to Recent times a series of tectonically controlled coastal embayments formed on the Pacific fore-arc side of the southern Central American island-arc system. Each of these basins shows characteristic stratal geometries and facies distributions reflecting the complex interaction of changes of sea level, volcaniclastic input. and tectonic activity (subsidence, uplift).

Sequential stratigraphic correlations based on sequence analysis and discontinuity surfaces indicate that eustatic sea-level changes control architecture, geometry, and facies distribution of depositional sequences at the level of second-order cycles. Owing to the particular tectonic position, complete sets of systems tracts are seldom developed. Volumınous sediment supply, especially durng episodes of strong volcanic activity, may overcompensate transgressions. Strong uplift may annihilate any sedimentary documentation or reduce sequences to a strongly condensed package with random preservation of estuarine or deltaic facies. The bounding unconformities (sequence boundaries) are traceable on a regional scale and are related at the level of second-order sequence boundaries to tectonic events that repeatedly affected the island arc during the episode in question.
\end{abstract}

\section{INTRODUCTION}

The southern Central American land bridge was formed at a suture zone between the Farallón Plate and proto-Caribbean crust. According to the chapter by Seyfried $e t$ al., the following stages of evolution can be distinguished: (1) formation of a primitive tholeiitic ridge (Albian-Santonian), (2) compression of the overriding plate margin (Campanian), (3) development of a mature island-arc system ranging from calc-alkaline arc through fore-arc and outer arc to trench slope (Maastrichtian-Eocene), (4) regional compressive uplift and subsequent repetitive opening of faultangle depressions (Oligocene-Recent).

In the early Paleocene, the outer arc became a morphological barrier between the fore-arc and trench slope, exerting a direct control on trench slope sedimentation. The strong middle Oligocene (Haq et al., 1988) fall of sea level could have enhanced the effects of Oligocene compressive uplift. As a result, extensive parts of the north and south Costa Rican fore-arc and outer arc areas were deeply eroded. In parts of the northern and central areas, marine sedimentation started again in the latest Oligocene; in the inner fore-arc of southern Costa Rica as well as in southwestern Nicaragua, however, Oligocene sedimentation was obviously continuous and most probably predominantly marine.

From the latest Oligocene until the Pliocene, a series of short-lived coastal embayments formed along both fore-arc and outer arc. The geometry of these coastal embayments was controlled by a combination of normal faults and strike-slip fault systems with dominantly transtensile regimes. From a structural point of view, the following categories of embayments can be recognized (for location, see Fig. 1):

1 coastal embayments bounded by normal faults (Malpaís Basin, Dominical Basin); 


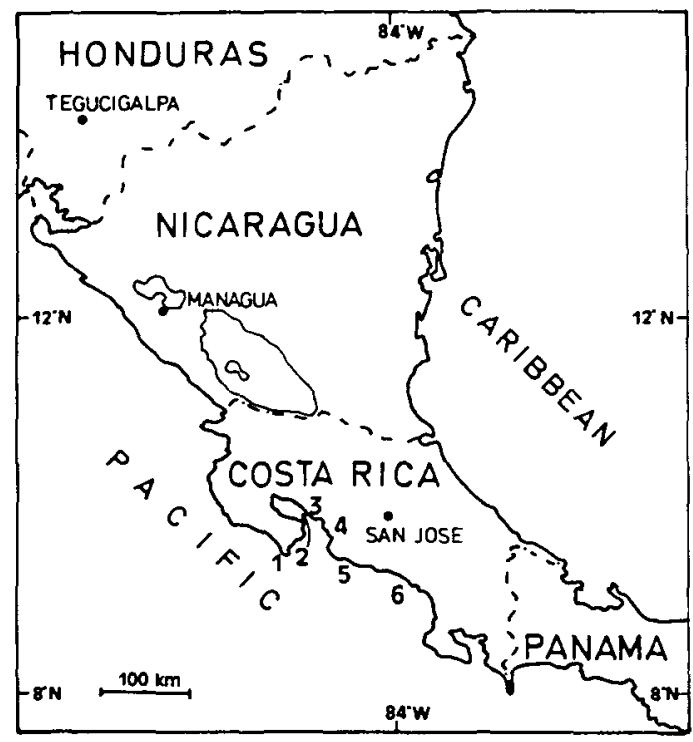

Fig. 1. Location map of Neogene forc-arc coastal cmbayments. (1) Malpaís Basin, (2) Gulf of Nicoya, (3) Punta Carballo Basin, (4) Punta Leona-Tarcolitos Basin, (5) Parrita Basin, (6) Dominical Basin.

2 coastal embayments created by fault-angle depressions (Punta Carballo Basin, the actual Gulf of Nicoya);

3 coastal embayments formed by transtensional strike-slip movements (Punta Leona-Tarcolitos Basin, Parrita Basin).

Each of these basins displays an individual structural and sedimentary history. Several tilting phases characterize the Malpais Basin, resulting in the formation of strongly reduced shallow-marine sequences separated by angular unconformities. The Punta Carballo Basin existed for a relatively short period of time and is characterized by tide-influenced sedimentation. In the Punta Leona-Tarcolitos Basin there are two distinctive stages of basin development: a uniform basal unit formed in an openshelf-beach system is followed by a higher unit characterized by differentiation in various sedimentary environments. In the Parrita Basin, transgressive-regressive sequence couplets are well developed on a background of strong subsidence. The Dominical Basin shows a simple development from an undifferentiated open shelf system to a small embayment.

The purpose of this paper is to demonstrate the extent to which sequence-stratigraphic concepts can be applied to siliciclastic shallow-water deposits from a convergent plate margin.

The general geological and tectonic setting of the Central American island-arc system and the sequence-stratigraphic interpretation of the deepwater deposits will be discussed in the papers by Seyfried et al. and Winsemann \& Seyfried.

\section{Conceptual model}

According to the concept of sequence stratigraphy (cf. Vail et al., 1977), sequences and their bounding unconformities are interpreted as forming in response to cycles of eustatic sea-level fluctuation. The fundamental stratigraphic unit is the depositional sequence, which is bounded by unconformities and their correlative conformities.

The bounding unconformities (sequence boundaries) are inferred to be produced by eustatic falls of sea level. Vail \& Todd (1981) distinguish between type 1 and type 2 sequence boundaries. A type 1 sequence boundary is characterized by both subaerial and submarine erosion and is formed when the rate of eustatic sea-level fall exceeds the rate of subsidence at the depositional shoreline break (Posamentier \& Vail, 1988). A type 2 sequence boundary is characterized by widespread subaerial erosion of the exposed shelf and a change within the sedimentary succession from progradational to aggradational stacking patterns. Type 2 sequence boundaries are formed when the rate of eustatic sealevel fall is less than subsidence rate at the depositional shoreline break (Posamentier \& Vail, 1988). A depositional sequence comprises a succession of three systems tracts. Type 1 sequences consist of lowstand, transgressive, and highstand systems tracts and are bounded at the base by type 1 sequence boundaries. Type 2 sequences consist of shelf-margin, transgressive, and highstand systems tracts and are bounded at the base by type 2 sequence boundaries. Both type 1 and type 2 sequences can be bounded at the top by either a type 1 or a type 2 sequence boundary. Haq et al. (1988) give a sequence-stratigraphic hierarchy and subdivide sequence-stratigraphic units into first-order cycles (about $250 \mathrm{Ma}$ long), second-order cycles (about 9-10 Ma long), third-order cycles (about 1- $2 \mathrm{Ma}$ long), and fourth-order or higher cycles (400-20 ka long).

Systems tracts are defined by their position within the sequence, their bounding surfaces, and by the 
stacking patterns of their constituent parasequences and parasequence sets. Systems tracts are inferred to be associated with a specific part of the eustatic cycle. Lowstand systems tracts will form during a time of rapid eustatic fall and early eustatic rise of sea level; shelf-margin systems tracts will form during a time of slow eustatic fall and early eustatic rise of sea level; transgressive systems tracts will form during a time of a rapid eustatic sea-level rise; highstand systems tracts will form during a time of a late eustatic rise, a eustatic stillstand, and a time of an early eustatic fall (Posamentier et al., 1988).

Parasequences are defined as a succession of genetically related depositional systems with progradational, retrogradational, or aggradational stacking pattern. Two or more parasequences form a parasequence set (van Wagoner et al., 1988).

Depositional sequences, systems tracts, parasequences and sets of parasequences are each bounded below and above by surfaces of regional or local extent, which provide a chronostratigraphic framework for correlating and mapping sedimentary rocks (van Wagoner et al., 1988).

\section{THE NEOGENE COASTAL EMBAYMENTS}

During latest Oligocene to Recent times, a series of tectonically controlled coastal embayments formed on the Pacific fore-arc side of the southern Central American island-arc system (Fig. 1). Each of these embayments shows characteristic sequences of shallow-marine strata, which reflect the complex interaction of (1) changes of sea level, (2) subsidence, (3) tectonic uplift, and (4) variable sediment supply (mostly volcanoclastic).

Two of these coastal embayments, each characterized by distinctive controlling factors, will be discussed in more detail. The Malpaís Basin shows a prevailing tectonic control, especially uplift and block faulting. The Parrita Basin reflects strong subsidence, probably in response to abundant sediment supply. Both document opposing extremes in basin development, with sedimentation being controlled either by tectonics or by eustasy.

\section{The Malpaís Basin}

The Malpaís Basin is located in the south of the Nicoya Peninsula (Fig. 1). The uppermost Oligocene to lower Pliocene shallow-marine sediments of the
Malpaís Basin make up the upper $250 \mathrm{~m}$ of an upper trench slope succession, $5000 \mathrm{~m}$ thick in total (cf. paper by Seyfried et al.).

Middle to upper Eocene shallow marine, carbonate ramp deposits (Calvo, 1987) mark the onset of shallow water sedimentation in the area. These carbonates are separated from the underlying upper trench slope deposits by an angular unconformity that cuts across slightly folded and intensely slumped strata, thus indicating previous compressive uplift. This set is again cross-cut by another angular unconformity, which dissects an intensely sheared substratum, exposing both ramp carbonates and older units in random order. Thus, it may be concluded that strong compressive uplift affected the entire outer arc and fore-arc area (cf. paper by Seyfried et al.). During early and mid-Oligocene times no sedimentation is documented. Mixed carbonate-clastic coastal bar systems of latest Oligocene age (Calvo, 1987; Schmidt, 1989) form the first deposits lying on the unconformity. They are followed by shallowmarine siliciclastic sequences, separated by major unconformities. The unconformities cut across tilted blocks, which each expose the previously formed stratigraphic sets. Regional compression must be inferred as a cause for tilting.

The sedimentary succession was described for the first time by Dengo (1962). Further workers (Schmidt-Effing, 1979; Lundberg, 1982; Baumgartner et al., 1984; Sprechmann, 1984) established several formal rock units; Mora (1985) presented the first sedimentological study. Astorga (1987), Calvo (1987), and Schmidt (1989) provided detailed facies analysis and interpretations of sequence dynamics of the deep-water deposits, carbonate systems, and siliciclastic shallow-water sediments, respectively. A preliminary summary of the tectono-sedimentary development of the Malpaís Basin was given by Seyfried et al. (1987).

\section{Bıostratıgraphic remarks}

Owing to the poor preservation of planktonic Foraminifera, biostratigraphic control is sparse. Available palaeontological data assign a mid to late Eocene age to the shallow-marine carbonates (Baumgartner et al., 1984; Mora, 1985; Calvo, 1987). Age determination of the siliciclastic shallow-marine deposits range from late Oligocene to early Miocene (Lundberg, 1982; Baumgartner et al., 1984; Mora, 1985) for the basal part of the succession, probably middle Miocene (personal communication. 
D. Pizarro, Micropaleontological Laboratory, Recope) for the middle part of the succession, and late Miocene to early Pliocene (Fischer, 1981: Goudkoff \& Porter, in Sprechmann, 1984) for the upper part.

\section{Facies descriptions and depositional environment}

Within the siliciclastic shallow-marine series, seven facies types were identified in the outcrops examined. It should be pointed out that grain size is commonly 1-2 size classes coarser than in comparable environments described in the literature (the same observation can be made for the Parrita Basin). A representative but idealized vertical section is shown in Fig. 2.

\section{Facies 1 (prodelta)}

This facies consists of several centimetre to decimetre-thick interbeds of siltstones and fine- grained sandstones. Shell debris and plant remains are rare. Frequency and thickness of the sandstone beds increase upwards slightly. The sandstones exhibit sparse planar lamination and normal grading. Occasionally basal contacts of the sandstones are scoured and show load structures. Soft-sediment deformation (e.g. flame structures, convolute lamination) is common. The siltstones show no visible sedimentary structures. Siltstone and sandstone beds show varying degrees of bioturbation. Trace fossils include Chondrites, Helminthopsis, Planolites, Terebellina; Ophiomorpha and Thalassinoides occur only in sandstone beds.

Facies 1 is interpreted as having been deposited in a prodelta position under varying energy conditions and high rates of sediment supply. The bioturbated siltstones are considered to have been deposited by suspension fall-out during fair weather conditions, representing 'normal' conditions of sedimentation. The graded and laminated sandstone beds can be related to suspension-laden currents under decreas-
PLAYA
SANTA TERESA
PLAYA
SANTA TERESA
PLAYA
PUNTA
MALPAIS
BARRIGONA

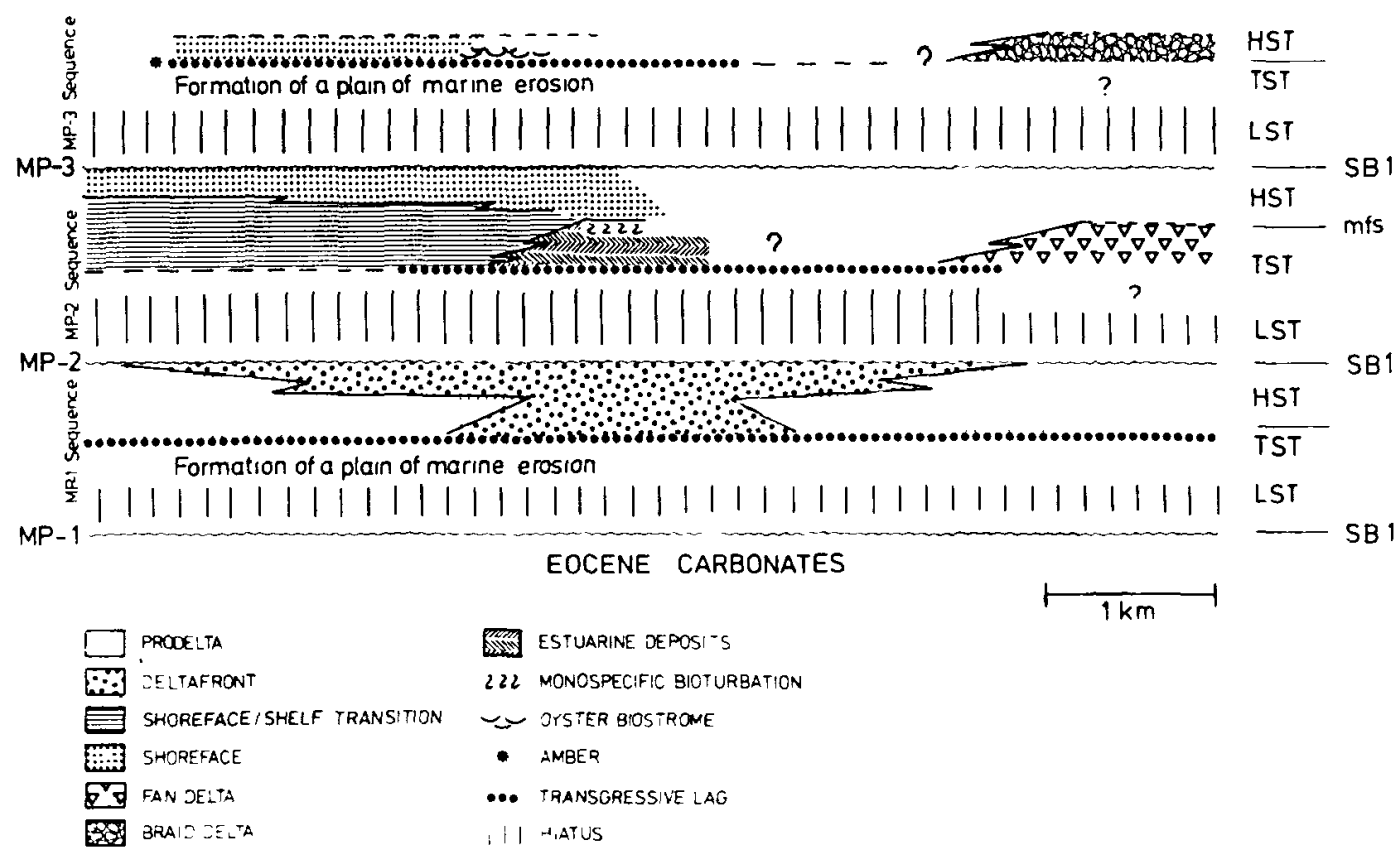

Fig. 2. Idealızed vertical succession and sequence development of the late Oligocene to early Plıocene Malpais Basin. The left column refers to nomenclature of sequence analysis: the right column refers to sequence-stratigraphic interpretation (modified after Schmidt. 1989). 
ing velocities. The sedimentary features and occurrence of scoured bases suggest sedimentation under storm weather conditions.

\section{Facies 2 (delta front)}

This facies consists of fine to coarse-grained centimetre to decimetre-thick bedded sandstones and may contain shell fragments. The sandstones exhibit horizontal lamination, low-angle planar crossstratification, current ripples, and synsedimentary deformation structures, such as flame structures, convolute lamination, and load casts. Basal bedding contacts are generally sharp and occasionally erosional. Some beds are graded and show erosional bases and rip-up clasts. The sandstones show moderate to strong and partly complete bioturbation with Ophiomorpha, Thalassinoides, escape structures, Chondrites, Helminthopsis, Terebellina, Teichichnus, and Planolites. This facies also exhibits massive sandstone beds without any visible stratification or bioturbation, and massive sandstone beds with primary bedding structures completely destroyed by biogenic reworking. The vertical succession suggests increasing energy levels and presumably upward shallowing, indicated by increase of grain size and increase of primary sedimentary structure.

This facies originated from suspension fall-out and bedload in a high energy delta-front position. Planar lamination can result from upper flow regime currents. Planar cross-stratified beds have been considered to form under similar conditions. The coarse-grained nature of the sandstones and current ripples suggest moderately strong tractional bottom currents. The massive sandstones lacking physical or biogenic structures are considered to be deposited from suspension fall-out in a more proximal deltafront position. The high density of burrows in some sandstone beds suggests a more distal position where bioturbation kept pace with sedimentation. Graded beds with erosional bases and rip-up clasts are interpreted as representing tempestites.

\section{Facies 3 (shelf-shoreface transition zone)}

Facies 3 is lithologically similar to facies 1 , but the grain size is somewhat coarser and soft-sediment deformation is less common. Sandstone beds predominate within this facies. They show sparse parallel lamination and some beds are characterized by low-angle cross-stratification. Bioturbation is rare and restricted to Ophiomorpha and Thalassinoides. This bioturbation mainly affects the tops of sandstone beds, which in turn commonly show sharp erosional basal contacts and normal grading. Concretion horizons are common.

Facies 3 is considered to represent a shelfshoreface transitional environment. The massive siltstones and sandstones represent deposition from suspension fall-out during fair weather conditions or below storm wave-base. The laminated and planar cross-stratified sandstones are deposited under higher energy conditions, indicating a slightly shallower environment. The graded, sharp-based sandstone beds are interpreted as indicating episodic storm events.

\section{Facies 4 (shoreface)}

This facies consists of centimetre to decimetre bedded, fine to coarse-grained sandstones. Physical sedimentary structures include parallel lamination, low-angle planar cross-stratification, and small-scale trough cross-bedding. Graded beds with sharp-based erosional contacts are common. Mollusc shells are common and often concentrated in small lenses. Bioturbation is moderate to strong. Ophiomorpha and Thalassinoides are predominant; Chondrites and Helminthopsis are less common.

Facies 4 exhibits sedimentary structures typical of a high-energy environment. Planar and trough cross-stratification have been considered to form under high-energy oscillatory flow conditions in the near-shore setting. The graded sharp-based beds together with small lenticular shell concentrations are considered to be tempestites.

\section{Facies 5 (estuary)}

Facies 5 is characterized by extremely fossiliferous medium to coarse-grained sandstones, which interdigitate laterally with deposits of the shelf-shoreface transition zone. The lower part of the succession exhibits lenticular mollusc concentration and/or gravel lags. The upper part shows parallel lamınation, low-angle planar cross-stratification, sigmoidal foresets, and bidirectronal cross-stratification. Grain sıze decreases in an upward direction. Withın these deposits a horizon $70 \mathrm{~cm}$ thick occurs that displays monospecific bioturbation by Thalassinoides.

This facies is interpreted to represent the estuarine-marine portion of a bar-built estuary. Lenticular mollusc concentrations and gravel lags are a 
product of concentration and reworking by currents, probably at the bottom of a small runnel. The sedimentary structures reflect moderate to high energy conditions in a shallow environment, and tidal influence is indicated by bidirectional cross-stratification suggesting deposition on a shoal.

\section{Facies 6 (fan-delta)}

This facies consists of decimetre-thick beds and lenses of poorly sorted, fine to coarse-grained breccias, matrix-supported conglomerates, clastsupported conglomerates with interbedded sandy layers, pebbly sandstones, and fine to coarse-grained sandstones. Sedimentary structures include lowangle planar cross-stratification, trough crossstratification, parallel lamination, and herring-bone cross-stratification. Some beds exhibit normal grading. Basal contacts are generally sharp and erosional. The beds show varying degrees of bioturbation, which is restricted to Ophiomorpha.

Facies 6 is considered to represent fan-delta deposits. The poorly sorted breccias are interpreted as sheet-flood deposits; the matrix-supported conglomerates have been deposited as debris flows. The sedimentary structures indicate reworking by marine processes in a high energy, shallow marine environment.

\section{Facies 7 (braid-delta)}

Lithologically, this facies consists of centimetre to decimetre-thick siltstones, which are characterized by a high content of organic material (plants, wood) and medium to coarse-grained sandstones with lenticular intercalations of conglomerates. The beds show low-angle planar cross-stratification, parallel lamination, trough cross-stratification, herring-bone cross-stratification, flaser bedding, and high-angle planar foresets.

This facies is interpreted as representing braiddelta deposits. Physical sedimentary structures indicate a high energy, delta-front environment with intercalated small distributary channels and mouth bar deposits. The siltstones with plant and wood remains represent low-energy braidplain deposits.

\section{Sequence analysis and sea-level history}

The siliciclastic shallow-marine series of the Malpais Basin are characterized by the presence of laterally traceable discontinuity surfaces, which subdivide the succession into the three depositional sequences (Fig. 2). The surfaces are numbered successively MP-1, MP-2, and MP-3. Depositional sequences are identified by the same number as their basal discontinuity surface.

The MP-1 discontinuity surface is identified as an angular unconformity by the truncation of underlying sequences. The MP-1 surface represents a wavecut platform showing pronounced microrelief and Gastrochaenolites borings. The MP-1 sequence starts with a conglomeratic lag deposit. This lag contains mainly cobbles of the underlying sequences, as well as basalt and radiolarite from Nicoya Complex exposures, and less common shells, rhodoliths, and shark teeth. Some of the components have borings filled with detritus of the overlying sediments. This is interpreted as having been deposited as a transgressive lag during a period of a relative sea-level rise. The overlying sequence comprises an offshoreonshore facies tract from prodelta to delta-front environments. The overall coarsening upward and shallowing upward trend reflects a prograding deltaic system, thus implying a relative fall of sea level.

The MP-2 discontinuity surface has been formed as a marine erosional surface, characterized by Thalassinoides burrows, filled with overlying coarser material. A basal conglomerate horizon is locally present; it contains cobbles derived from the underlying shallow-marine sequences, basalt, radiolarite, and quartz components, as well as abundant shells and shell fragments. Basinwards, this surface merges into a correlative conformity. The MP-2 sequence exhibits an offshore-onshore facies tract and comprises laterally interfingered fan-delta, estuarine, and shelf-shoreface transition zone environments, which gradually pass into shoreface environments. The vertical succession indicates a transgressiveregressive couplet.

The MP-3 boundary is similar to the MP-1 discontinuity surface. The major distinguishing feature is the occurrence of amber within the overlying conglomeratic lag deposit. This lag is interpreted as a transgressive lag due to a relative sea-level rise. The MP-3 sequence is only poorly preserved and comprises shoreface and braid-delta deposits.

\section{Evolution of the Malpais Basin}

Based on detailed measurement and description of sections, available palaeontological data, and sequence analysis, the tectono-sedimentary develop- 
SE

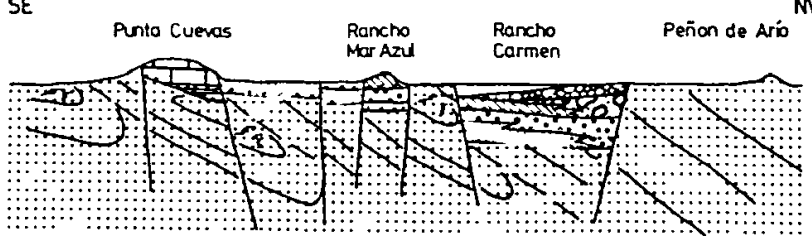

LATE MIOCENE TO EARLY PLIOCENE
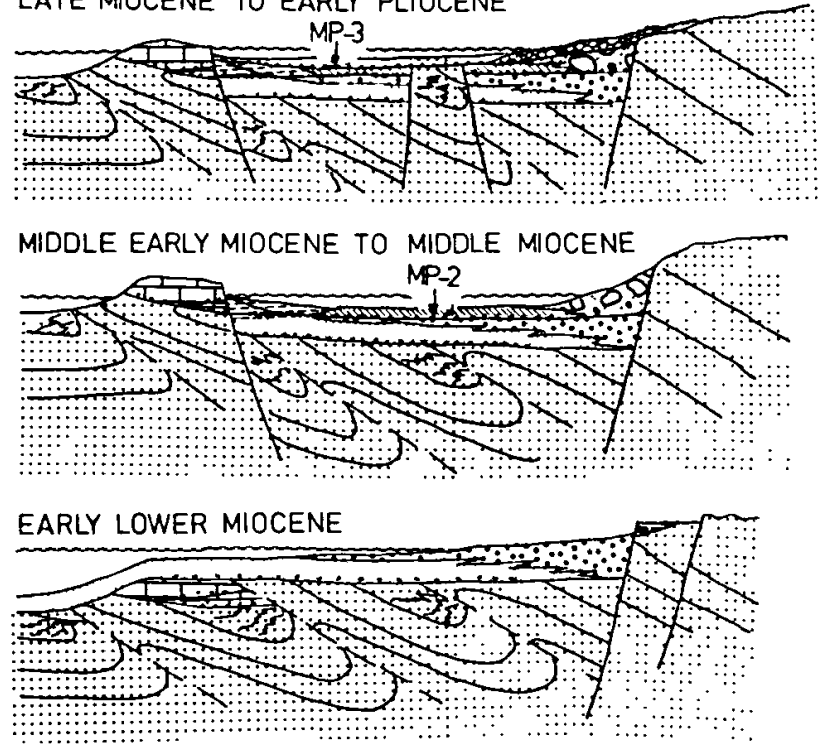

\section{LATE OLIGOCENE}

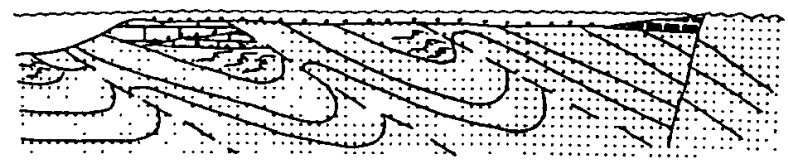

EARLY OLIGOCENE

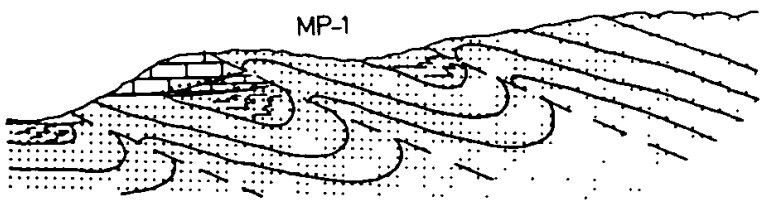

\section{EOCENE}

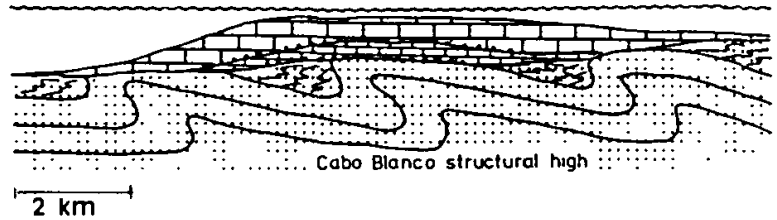

EARIY PLIOCEIE

further differential upluft; sedimentation of shoreface to brald delta deposits during relative bighstand of sed-le:el

MIOCEIE TO CARLY PLIOCEXE

during relative rise of sea-level formation of a plain of urine erosion and a transgressive laq charactersted by anber

$\longrightarrow$ shoreface deposits

Pogog traid delts deposits

MIDOLE MIOCLNE

differential uplift

MIDOLE EARLY MIOCEXE

foration of arine erosional unconforaity (aP-21 and

transgressive lag during rising sed-level

estuarine deposits

CO: fan delta deposits

delta progradation during relative highstand of sed-level and beginning fall of sed-level

[_] prodelta deposits

$\because \because:$ del ta front deposits

change in tectonic style towards distensive tilting. Rise of sea-level produces a plain of arine erosion. Local foration of nearshore carbonates. Further rise of sealevel creates a transgressive lag

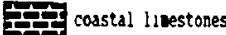

further cospressive uplift; subaerial erosion

G.?.] deep water deposits (nusnly turbidites!

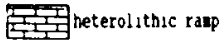

II casbonate rasp

MIDOLE TO WTE COCERE

progressive grouth of a carbonate raup upon the Cabo Blanco structural high. Contact between the heterolithic ranp and carbonate rarp cost probably represents hid to late Eocene fall of sea-level

\section{EARLY COCDMI}

compressive uplift causes gra.itational erosion on antaforas and accunulation of sluaps in synforas

Fig. 3. Tectono-sedımentary development of the Malpais Basın (modified after Seyfred et al. (1987) and Schmıdt (1989)). See text for further explanation. 
ment of the Malpaís Basin can be reconstructed as follows (Fig. 3).

The shallow-marine history of the Malpaís Basin starts in middle to late Eocene times, with progradational growth of a carbonate and heterolithic ramp system after previous compressive uplift, which transformed the former upper trench slope into an external outer arc.

Between the end of the late Eocene and the terminal Oligocene, another compressive event occured, which caused strong shearing and finally led to widespread erosion.

From the latest Oligocene onward, isostatic relaxation produced tilting of blocks parallel to the outer edge of the outer arc. Thus, younger sequences start with an angular unconformity (MP-1), which in places appears as a wave-cut platform bored by Gastrochaenolites and covered with a thin veneer of coarse clastics. A concomitant relative sea-level rise is suggested by the formation of mixed carbonateclastic depositional systems that cover near-shore areas (Nosara region, Calvo, 1987). Carbonate detritus derived from these shoals has been reworked among the lower Miocene deltaic sediments, evidencing continuous tectonic activity (Schmidt, 1989). The prograding delta sequence should have formed during a relative highstand of sea level and one, or several, episodes of falling sea level.

In the outcrops examined, the MP-2 marine erosional unconformity is not angular and thus might correspond to a relative fall of sea level rather than to tectonic uplift (which always follows the tilting style). The basement components in the following conglomeratic lag, however, prove tilting revival. Correspondingly, the marine unconformity should be considered a correlative conformity. Tilting fits well with the fact that the overlying mid-Miocene sediments were deposited in a completely different environment: small coastal embayment where estuarine deposits closely interfinger with fan-delta and shallow-shelf deposits. The estuarine sequence is topped by a horizon with monospecific bioturbation by Thalassinotdes.

After another phase of tilting the MP-3 angular unconformity was produced. Middle Miocene to lower Pliocene deposits start with an amber-bearing transgressive lag, which in turn covers a wave-cut platform. In contrast to the former depositional sequences, the present one does not display facies types that unambiguously prove a highstand signal in the basin-fill.

\section{The Parrita Basin}

The Parrita Basin is located on the Pacific Coast of central Costa Rica (Fig. 1). Basin geometry is defined by a strike-slip fault system (Astorga et al., 1989: Schmidt, 1989). More than $1300 \mathrm{~m}$ of shallowmarine deposits accumulated during the mid-Miocene and probably early Pliocene on a continually subsiding block. Facies types reflect a wide environmental spectrum, ranging from deeper shelf environments through tidal-flat deposits to paralic conditions. The basement of the sedimentary succession is known from geological mapping in the surrounding areas and is represented by basaltic rocks of the Nicoya Complex. The Neogene sequence is topped by the alluvial deposits of the modern Parrita Valley.

The sedimentary suite of the Parrita Basin was described for the first time by Dengo (1962). Shallow-marine deposits are included among the Miocene 'Punta Carballo Formation' (Kuypers, 1979; Fischer, 1981; Sprechmann, 1984). Geological studies concerning sedimentology, environmental, and sequential dynamics, as well as palaeoecological aspects, have been carried out in the last few years by Seyfried \& Aguilar (1984), Seyfried et al. (1985), Seyfried \& Sprechmann (1985), and Schmidt (1989).

\section{Biostratigraphic remarks}

Kuypers (1979) and Sprechmann (1984) claim a midMiocene age for the Punta Carballo Formation. Fischer (1981), however, argued that the age of the formation ranges from middle Miocene to late Miocene. F. Rivier (Escuela Centroamericana de Geologia, Universidad de Costa Rica, personal communication) emphasizes an early Pliocene age for the upper part of the succession. Planktonic Foraminifera of the basal part of the sequence belong to zone N9 (after Blow $(1969,1979)$, cited in Seyfried et al., 1985).

\section{Facies description and depositional environments}

The type section at Punta Judas (Fig. 4) shows 12 facies types. The mainly litharenitic volcaniclastic sediments characteristically show an intricate mixing of two grain populations: relatively well-preserved first-cycle grains, such as feldspars and calcalkaline volcanic rock fragments, are almost equal in abundance to heavily altered 'Nicoya Complex' grains (mostly basalt fragments). It is obvious that a 'fresh' influx of calc-alkaline arc grains had un- 
Fig. 4. Generalized type section (Punta Judas Section) of the shallow-marine sequences of the middle Miocene to early Pliocene(?) Parrita Basin (modified after Seyfried et al. (1987) and Schmidt (1989)). The vertical succession compnses four transgressiveregressive cycles (PA-0 to PA-4 sequences).

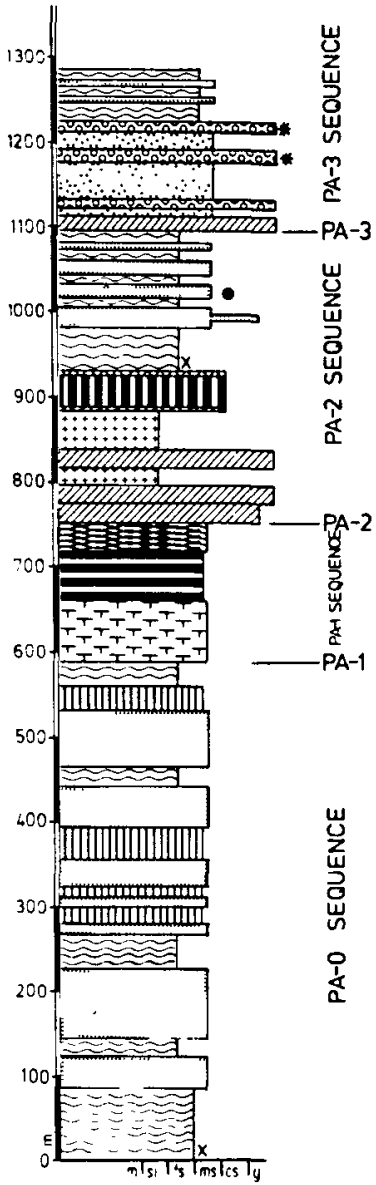

PARALIC ENVIRONMENTS

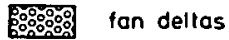

coostal sand bors

sigh shilly hypersaline lagoon (eg Vermetide biostromes)

IIIIII $n$-mesohaline lagoon (coprolithe loyers. Panamicorbula accumulation

\section{TIDAL BASIN}

::: mangrove swomps + intertidal chanels

DIIT main subtidal chonnels

(coarse clastic tidal bundle sets)

SHELF

shorefoce (steeply and swaley

E cross - laminaled sandstones upper flow regime deposits)

shelf (HCS sandstones and shelf muds)

transitional zone llaminated sandstones with frequent intercalations of biociastic tempestites

\section{DELTA-RELATED ENVIRONMENTS}

IIIIII distributary mouth bar

cross - bedded sandstones)

proximal delta front - episodes of heavy sand suspension fall out (massive sondstones)

distal delta front - episodes of intermiltent sand suspension fall-out llaminated sandstones. coquinas, and concretion horizons

$x$ isotopic thanatocoenosis

- Thalassinordes horizon

* amber hindered access to the basin, whereas the Nicoya Complex grains already had a history; they are considered to derive from adjacent weathered uplifts.

Most facies are extremely fossiliferous and exhibit varied trace fossil assemblages, so that sedimentological interpretation can be thoroughly controlled and completed by palaeoecological data.

\section{Facies 1 (distal delta-front)}

This facies consists of alternating fine to mediumgrained, decimetre thick, well bedded, massive sandstones, laminated sandstones, and highly bioturbated sandstones containing a high diversity of molluscs (Seyfried et al., 1985). The sandstones are characterized by abundant regularly spaced concretion levels, parautochthonous shell accumulations, and monospecific assemblages of molluses (e.g. Atrina sp., Semele sp.) in life position (biocoenosis, cf. Seyfried et al., 1985).

Facies 1 is interpreted as having been deposited within a deltaic environment in a distal delta-front position. The massive sandstones most probably originated from suspension fall-out. The bioturbated sandstones reflect slightly diminished sediment influx, so that bioturbation was able to keep pace with sedimentation. Laminated sandstones and particularly the occurrence of biocoenoses reflect reduced sediment input or even short episodes of no net sedimentation. 


\section{Facies 2 (proximal delta-front)}

Lithologically, this facies consists of fine to mediumgrained homogeneous sandstones without physical sedimentary structures and with very scarce bioturbation. The sandstones may contain rare mollusc shells and isolated concretions.

This facies is considered to reflect a position in a proximal delta-front environment. The lack of any structure within the sandstones and the low content of molluscs reflect a high sedimentation rate, attributed to intense suspension fall-out.

\section{Facies 3 (distributary mouth bar)}

Facies 3 is made up of decimetre thick, bedded, fine to medium-grained sandstones, with common concretion horizons, and laminated fine to mediumgrained sandstones, which exhibit low-angle planar cross-stratification. Bioturbation with Ophiomorpha and Thalassinoides is moderately common.

This facies clearly reveals higher energy conditions than facies 2. Planar lamination and low-angle planar cross-stratification are considered to result from upper flow regime currents. The sandstones of this facies type are therefore interpreted to represent mouth bar deposits within a deltaic environment.

\section{Facies 4 (shelf)}

Facies 4 consists of alternations of parallel laminated, fine-grained sandstones, fine-grained sandstones with primary bedding structures that have been completely destroyed by bioturbation, and fine to medium-grained, decimetre thick, bedded sandstones displaying sharp erosional basal contacts, hummocky cross-stratification, and Ophiomorpha burrows, which mainly affect the tops of the sandstone beds. Intercalations of shell beds and lenticular shell accumulations are common.

Facies 4 is interpreted to represent a shelfshoreface transitional environment. The parallellaminated and bioturbated fine-grained sandstones reflect sedimentation from suspension fall-out within a relatively tranquil environment and probably represent fair weather conditions. Conversely, the sedimentary structures of the fine to medium-grained sandstones indicate conditions of waning flow and appear to be storm deposits. Shell beds and lenticular shell accumulations are densely packed with Anadara (Scapharca) sp., a mesohaline bivalve. and hence must be considered as tempestites (Seyfried \& Sprechmann, 1985).

\section{Facies 5 (shelf)}

This facies is characterized by alternations of laminated or massive argillaceous siltstones and mudstones with fine to medium-grained sandstones that alternatingly exhibit horizontal and lowangle cross-stratification (interpreted as hummocky cross-stratification).

This facies is attributed to a shelf environment between fair weather wave-base and storm wave-base. The silt- and mudstones of this facies probably represent the deepest deposits of the section, with sandy intercalations indicating occasional waveinduced turbulence.

\section{Facies 6 (shoreface)}

This facies type consists of well-bedded, fine to medium-grained sandstones. Physical sedimentary structures include parallel lamination, small-scale trough cross-stratification, steeply inclined planar foresets and swaley cross-stratification. Moderate to strong bioturbation is restricted to Ophiomorpha.

The predominance of physical sedimentary structures formed under high-energy conditions verify the sedimentation in a shoreface position. This facies is dominated by both bidirectional wave motion and unidirectional currents.

\section{Facies 7 (main tidal channels)}

Lithologically, this facies is made up of centimetre to decimetre-thick, bedded, medium-sand grained to pebble deposits. The beds exhibit thin horizontal bedding, small-scale and large-scale trough crossstratification, steep planar foresets, and decimetric sigmoidal foresets with well-developed toesets. These foresets exhibit a marked grading from medium pebble size to medium sand size and are separated by double mud drapes, thus proving their origin as tidal bundles.

Sedimentary structures and the occurrence of tidal mud drapes verify this facies type to be originated in subtidal and intertidal channels.

\section{Facies 8 (mangrove swamps)}

The sediments of this facies type are composed of laminated, wavy-bedded sets of argillaceous silt- 
stones, and medium to coarse-grained sandstones. Some thicker sandstone beds show grading and lenticular channel fills with basal rip-up clasts. Wood debris is often concentrated in thin sheets; leaves are common among argillaceous layers. Thalassinoides and Skolithos burrows are filled with medium to coarse-grained sand. Pholas borings have been observed mainly in the silty facies.

This facies is assigned to a mangrove swamp environment of a tropical tidal flat. The sandstone intercalations and foresetted mud-chip accumulations are interpreted as landward tempestites.

\section{Facies 9 ( $\beta$-mesohaline lagoon)}

The deposits of this facies are fine to mediumgrained sandstones with densely packed accumulations of Corbula (Panamicorbula) sp. as well as several coprolite layers.

The dominance of Corbula (Panamicorbula) sp., a mesohaline bivalve (Seyfried et al., 1985), suggests an interpretation as hyposaline lagoonal deposits.

\section{Facies 10 (hypersaline lagoon)}

This facies is characterized by biostromes of the vermetid gastropod Petaloconchus sculpturatus (Seyfried et al., 1985). Giant bivalves and gastropods are common accessory faunal elements.

The vermetide biostromes originated in an ephemeral, extremely shallow, and most probably hypersaline lagoon.

\section{Facies 11 (coastal sand bars)}

Lithologically, this facies is similar to facies 6 . Additional sedimentary structures comprise convolute lamination, escape structures, climbing ripples, and wave ripples reflecting general high sediment supply. This facies contains abundant 'sand dollars' (Melitta sp.), a sea urchin, which is typical for the breaker zone (Seyfried et al., 1985).

The sedimentary structures and the occurrence of Melitta sp. place this facies in an extremely shallow marine setting under high-energy oscillatory flow conditions. This is characteristic for coastal sand bars.

\section{Facies 12 (fan-delta)}

Facies 12 exhibits the same lithological and sedimentary features as facies 6 of the Malpais Basin.

\section{Sequence analysis and sea-level history}

The designation of discontinuity surfaces and sequences follows the same pattern as used for the Malpaís Basin. The surfaces and corresponding sequences are numbered PA-1, PA-2, and PA-3 (Figs 4, 6). The PA-1 discontinuity surface is characterized by a change from distal delta-front deposits to sediments of the shelf-shoreface transition zone. This surface is interpreted as having been produced under submarine conditions during a transgression. which was preceded by a relative fall of sea level. The PA-2 surface is characterized by the erosional incision of subtidal channels into shoreface deposits. The development of such discontinuity features is interpreted to be related to periods of low sea level (Shanmugam, 1988). The PA-3 discontinuity surface is an angular unconformity produced by tectonic uplift, which in turn is proved by the overlying fandelta deposits, and probably concomitant with a period of relative fall of sea level.

The vertical sequence development, indicated by the facies framework and stratal pattern within the sedimentary record, points out four environmental scenarios. These scenarios reflect different sequence development according to variable interaction between rates of eustasy, subsidence, and sediment supply (Fig. 5).

\section{Scenario A (PA-1 sequence)}

A thick succession of delta-front deposits characterizes this situation. Sedimentological and biostratonomic features indicate three different facies types. which formed during a time of relatively rising sealevel, controlled by a continuing subsidence and variable sediment input.

1 Massive sandstones reflect high sedimentation rates during episodes of heavy sand suspension fallout. Local conditions were: uplift of the hinterland to produce strong erosion, and/or a short-term drop of sea level to produce prograding delta systems.

2 Alternations of laminated, commonly bıoturbated sandstones, parautochthonous shell accumulations. and biocoenoses reflect relatively low sedimentation rates. Dunng a short-term rise of sea level, the delta became an estuary that served as a sediment trap and little sediment could reach the depocentre. Alternations of facies types 1 and 2 were produced by fluctuations of sediment influx owing to epısodic shifting of the delta system - producing a local 

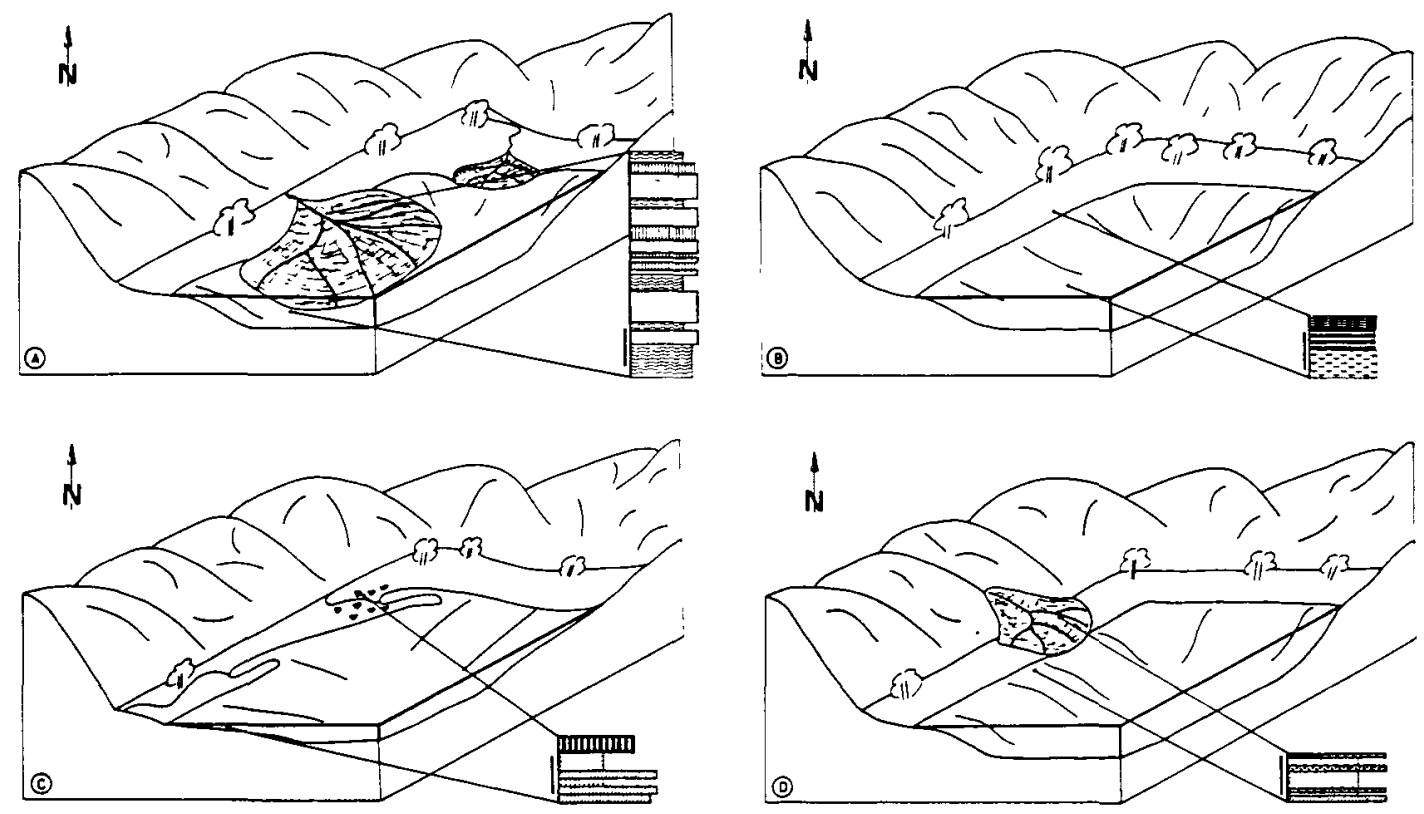

Fig. 5. Environmental scenarios for the sedimentary development of the Parrita Basin, reflecting different sequence development according to variable interaction between rates of eustasy, subsidence, and sediment supply. See text for further explanation. Key for columns corresponds to Fig. 4; bars equal $100 \mathrm{~m}$.

relative sea-level rise, climate changes, or shortterm transgressive episodes.

3 Interbeds of very low-angle planar cross-bedded sandstones, massive sandstones, and concretion horizons indicate relatively low sedimentation rates from continuing suspension fall-out. Concretion horizons, strong bioturbation, and small-scale lamination are characteristic for low rates of sedimentation. Massive sandstones, containing a sparse fauna, indicate continuing sedimentation from suspension fall-out. To have produced such a facies, a highstand of sea level and a high rate of sediment input would have been needed.

\section{Scenario $B(P A-2$ sequence)}

This situation reveals a transgressive-regressive couplet, which is superimposed by a general shallowing upward trend. The succession starts with sediments of the shelf-shoreface transition zone, is followed by shelf sediments, and then grades upwards into shoreface sediments. This pattern must have been produced by a rise and highstand of sealevel and the start of a fall of sea level.

\section{Scenario C (PA-3 sequence)}

During a relative lowstand of sea level, subtidal deposits formed in nearshore areas, and the marginal regions are characterized by deposits of mangrove swamps and lagoons.

\section{Scenario $D$ (PA.3 sequence)}

This scenario also reflects lowstand of sea level. In contrast to scenario $\mathrm{C}$, fan-deltas interfingering with coastal sand bars indicate contemporaneous tectonic activity.

\section{SEQUENCE-STRATIGRAPHIC INTERPRETATION}

Sequence analysis of the Malpaís succession indicates three transgressive-regressive sequences separated by discontinuity surfaces. In terms of sequence stratigraphy these sequences correspond to depositional sequences bounded below and above by unconformities and their correlative conformities. 
The MP-1 and MP-3 sequence boundaries are developed as angular unconformities and correspond to type 1 sequence boundaries, which formed during a rapid fall of relative sea level. Truncation of underlying sequences gives evidence for simultaneous local uplift and/or tilting of blocks. The MP-2 sequence boundary is also developed as a type 1 sequence boundary and formed as a marine erosional surface owing to a relative fall of sea level.

\section{The MP-1 sequence}

A slow relative rise of sea level produced a plain of marine erosion. With continuing rise of sea level a conglomerate bed developed. The plain of marine erosion and the overlying lag deposit are interpreted as representing the transgressive systems tract of this depositional sequence. The following prodelta sediments reflect the deepest sedimentary environment within the MP-1 sequence and are considered as having been deposited during a period of relative highstand of sea level. Regressive conditions, caused by a relative fall of sea level, are indicated by deltafront deposits, which prograde over the prodelta deposits. This succession of prograding deltaic deposits is considered as representing the highstand systems tract.

\section{The MP.2 sequence}

The MP-2 sequence boundary developed owing to a relative fall of sea level. This fall produced a marine erosional surface, which is traceable basinwards into a correlative conformity. A basal conglomerate, overlain by laterally interdigitating estuarine deposits and deposits of the shelfshoreface transition zone, is interpreted as having been formed during a relative rise of sea level. This succession represents the transgressive systems tract. The highstand systems tract contains prograding shoreface deposits. The stratigraphic position of the fan-delta deposits within this sequence is not clear owing to outcrop conditions.

A horizon with extremely strong monospecific bioturbation by Thalassinoides at the top of the estuarine deposits indicates hardground conditions (Kidwell, 1984) with low or even no net sedimentation. This horizon is interpreted as a flooding surface. This surface (maximum flooding surface, $\mathrm{cf}$. Baum \& Vail, 1987) marks the boundary between the transgressive systems tract and the highstand systems tract.

\section{The MP-3 sequence}

Uplift and block faulting produced an angular unconformity (MP-3 sequence boundary). A plain of marine erosion, covered by an amber-bearing conglomerate, is interpreted as the transgressive systems tract. This interpretation implies a preceding fall of sea level. The transgressive succession is overlain by an oyster biostrome and shoreface deposits; the stratigraphic position of braid-delta deposits within the sequence is unclear.

The following general conclusion can be drawn for the shallow-marine series of the Malpaís Basin.

1 Lowstand systems tracts are missing.

2 Transgressive systems tracts are represented by wave-cut platforms, transgressive lags, and mixed carbonate-clastic marginal-marine deposits.

3 Highstand systems tracts reflect various sedimentary environments depending on interaction of controlling factors. High sediment influx produced prograding delta systems.

\section{Parrita Basin}

The shallow-marine Parrita succession (Fig. 6) can be subdivided into four depositional sequences bounded by discontinuity surfaces, interpreted to represent sequence boundaries.

\section{The PA.O sequence}

Owing to outcrop conditions the basal boundary of this sequence cannot be observed. The PA-0 sequence consists of a succession of thick deltaic deposits. Within this succession the vertical arrangement of deltasc depositional systems forms genetically related units, interpreted to represent parasequences. The parasequences consist of combinations of facies type 1 (distal delta-front, characterized by episodes of intermittent sand suspension fall-out; numbering according to facies description of the Parrita Basin), facies type 2 (proximal delta-front, characterized by episodes of heavy sand suspension fall-out), and facies type 3 (distributary mouth bar, characterized by very low-angle planar cross-bedded sandstones). Two general combinations of these facies types can be distinguished forming parasequence sets.

Parasequence set $I$ shows an overall aggrading stacking pattern. Such a pattern is only possible if there is an equilıbrium between sediment influx, subsidence, and relative change of sea level (Vail et 


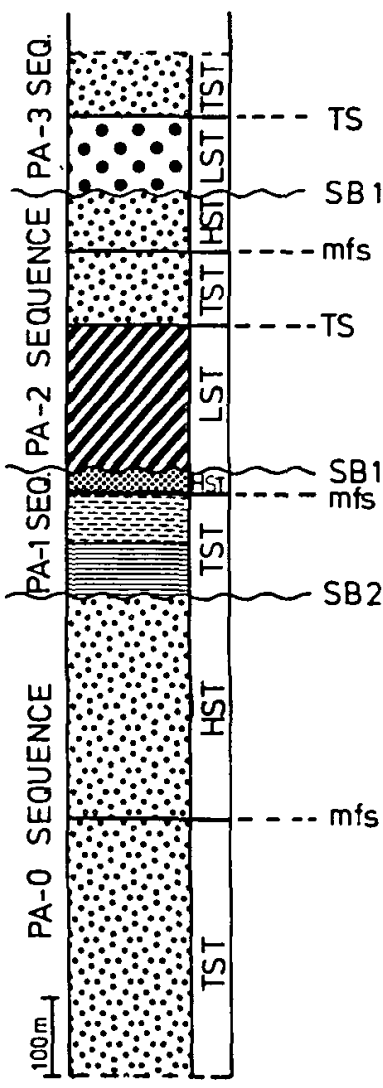

Fig. 6. Sequence-stratigraphic interpretation of the Parrita Basin (key as for Fig. 7).

al. , 1977). Parasequence set 2 contains parasequences with an overall prograding pattern, reflecting regressive conditions.

Parasequence set 1 forms the lower part of the PA-0 sequence. The aggrading stacking pattern of set 1 is interpreted as having been established during rising sea level, high sediment influx, and continuing subsidence, representing the transgressive systems tract of the PA-0 sequence. Biocoenoses, characterized by Atrina sp. and Semele sp. in life position. occur within the basal parts. This feature indicates periods of reduced sediment influx due to flooding events during the relative rise of sea level. Therefore, these horizons are considered to be marine-flooding surfaces.

The upper part of the PA-0 sequence consists mainly of parasequence set 2 . The overall prograding pattern of this part of the sequence indicates regressive conditions. It is interpreted as having been deposited during an early fall of sea level representing the highstand systems tract of the PA-0 sequence.

\section{PA-1 sequence}

The boundary between the PA- 0 and PA- 1 sequence is formed by a marine erosional surface and is characterized by the change from delta-front deposits to deposits of the shelf-shoreface transition zone. Since no obvious evidence of subaerial erosion can be observed, this surface is interpreted as having been formed in response to a slow fall of relative sea level and represents a type 2 sequence boundary. The transgressive-regressive couplet of the PA-1 sequence consists of the following components.

1 Deposits of the shelf-shoreface transition zone exhibit a retrograding pattern which is characteristic for transgressive conditions. This part of the sequence is correlated with the transgressive systems tract, possibly containing elements of the shelfmargin systems tract.

2 A coarsening and shallowing upwards sequence indicates a relative highstand of sea level and a subsequent relative fall in sea level. This part is considered to represent the highstand systems tract of the PA-1 sequence.

\section{PA-2 sequence}

The PA-2 sequence boundary is represented by erosional tidal channels in shoreface sediments. This surface is correlated with the development of a type 1 sequence boundary during a relative fall of sea level. The lower part of the PA-2 sequence is made up of tidal-flat deposits, which were deposited after the relative fall of sea level. Their stratigraphic position within the sequence permits correlation with the lowstand systems tract. A clear facies change from tidal to deltaic deposits reflects the transition to transgressive conditions. The occurrence of a biocoenosis (Semele sp. in life position) represents a transgressive surface. As with the PA-1 sequence, a succession of deltaic sediments was deposited during transgressive and regressive times. The bounding surface between the transgressive systems tract and the highstand systems tract (maximum flooding surface) is marked by a Thalassinoides horizon (compare with MP-2 sequence of the Malpaís Basin). 


\section{PA-3 sequence}

The PA-3 sequence boundary is developed as an angular unconformity. This surface was produced by tectonic uplift and probably reinforced by a relative fall of sea level. It represents a type 1 sequence boundary. In response to the tectonic movement, fan-delta sediments were deposited and form the lower part of the PA-3 sequence. These deposits represent part of the lowstand systems tract and the transgressive systems tract. The transgressive character of the upper fan-delta deposits is supported by the occurrence of amber (compare with MP-3 sequence of the Malpaís Basin). The discontinuity surface between the transgressive and the highstand systems tract reflects a clear change in facies to delta-front sediments, which were deposited during the highstand systems tract.

\section{Interaction of controlling factors}

The sequence-stratigraphic interpretation of the shallow-marine Malpaís and Parrita Basins clearly reveals similarities of systems tract architecture within these basins. The statements given in this section are valid for the Malpaís and Parrita Basins and can be applied to all fore-arc coastal embayments of the southern Central Amencan island-arc system (Schmidt, 1989; see paper by Kolb \& Schmidt).

The systems tracts show characteristic stratal patterns and facies architecture. Lowstand systems tracts are characterized by non-marine deposits (e.g. coastal plain deposits, fan-delta deposits), marginal marine deposits (e.g. estuarine deposits, tidal deposits) or a hiatus. Transgressive systems tracts and highstand systems tracts reflect various sedimentary environments, including the formation of a plain of marine erosion and/or a transgressive lag. This indicates that not only changes of sea level, but also vanous interactions of sediment influx, uplift, and subsidence control formation of facies types. The facies associations within the transgressive and highstand systems tracts reveal the following general relations between uplift/subsidence, rate of sedimentation, and changes of sea level.

1 Transgressive systems tract:

(a) uplift $>$ rise of sea level = formation of fandeltas, interdigitated with shelf deposits:

(b) subsidence $=$ rise of sea level + high rate of sedimentation - formation of thick prograding or aggrading delta systems;

(c) subsidence < rise of sea level - formation of transgressive shelf deposits;

(d) subsidence $>$ rise of sea level - formation of

Thalassinoides horizon.

2 Highstand systems tract:

(a) uplift $>$ fall of sea level - formation of coastal plains with braid-delta systems;

(b) subsidence $=$ fall of sea level + high rate of sedimentation - thick aggrading shoreface deposits;

(c) subsidence $<$ fall of sea level - formation of prograding shelf-beach systems.

The following surfaces and sequence boundaries to define depositional sequences and systems tracts can be recognized.

Type 1 sequence boundary (cf. Vail \& Todd, 1981)

Regional angular unconformities as well as subaerial and submarine erosional surfaces are interpreted to be type 1 sequence boundaries. They are characterized by subaerial exposure and erosion or submarine erosion, the formation of root horizons, and the deposition of non-marine or very shallow marine (e.g. estuarine or lagoonal) facies types about the sequence boundary.

Type 2 sequence boundary (cf. Vail \& Todd, 1981)

Surfaces without obvious evidence of subaerial or submarine erosion, but characterized by a significant facies change are interpreted as type 2 sequence boundaries.

\section{Transgressive surfaces}

Marine flooding surfaces above the lowstand systems tract, indicated by a veneer of conglomerates, a shell lag or a biocoenosis, are interpreted as transgressive surfaces.

\section{Maximum flooding surface}

A horizon of monospecific bioturbation by Thalassinondes, which indicates hardground conditions, is interpreted as a maximum flooding surface.

\section{Basin to basin correlation}

The reconstruction of sedimentary basin development and basin dynamics of the Neogene coastal embayments demonstrates a widely varıed lithology and facies distribution (Schmidt. 1989). Therefore 
a comprehensive correlation of different basins is often problematic. The application of sequencestratigraphic criteria, however, gives a more detailed insight in basin-wide sedimentary dynamics and may be helpful for basin to basin correlation (Fig. 7).

The Malpaís Basin and the Parrita Basin are two examples reflecting the high diversity of basin development in a tectonic realm, such as the fore-arc setting of an island-arc system. In the Malpaís Basin repetitive tilting phases clearly control sequence development and eustatic changes only contribute an overprint. The Parrita Basin reflects strong subsidence and primary eustatic control over sequence development.

Two marker beds correlate between these two basins:

1 an amber-bearing conglomerate;
2 a horizon with extreme Thalassinoides burrows.

Both marker beds occur only once in each basin and therefore are regarded to be unique events.

The amber-bearing conglomerate occurs above discontinuity surfaces developed as angular unconformities which are interpreted as type 1 sequence boundaries (MP-3 and PA-3 surfaces). Biostratigraphic data indicate late Miocene to early Pliocene ages for the MP-3 sequence. The same age can be assumed for the PA-3 sequence. Within both basins, the Thalassinoides horizon seems to form the discontinuity surface between highstand and transgressive systems tracts of the underlying sequence (MP-2 and PA-2 sequences). Age determination within the Malpaís Basin reveals a probable middle Miocene age for the MP-2 sequence. This coincides with palaeontological data of the Parrita Basin.
Malpaís Basın Parrita Basin

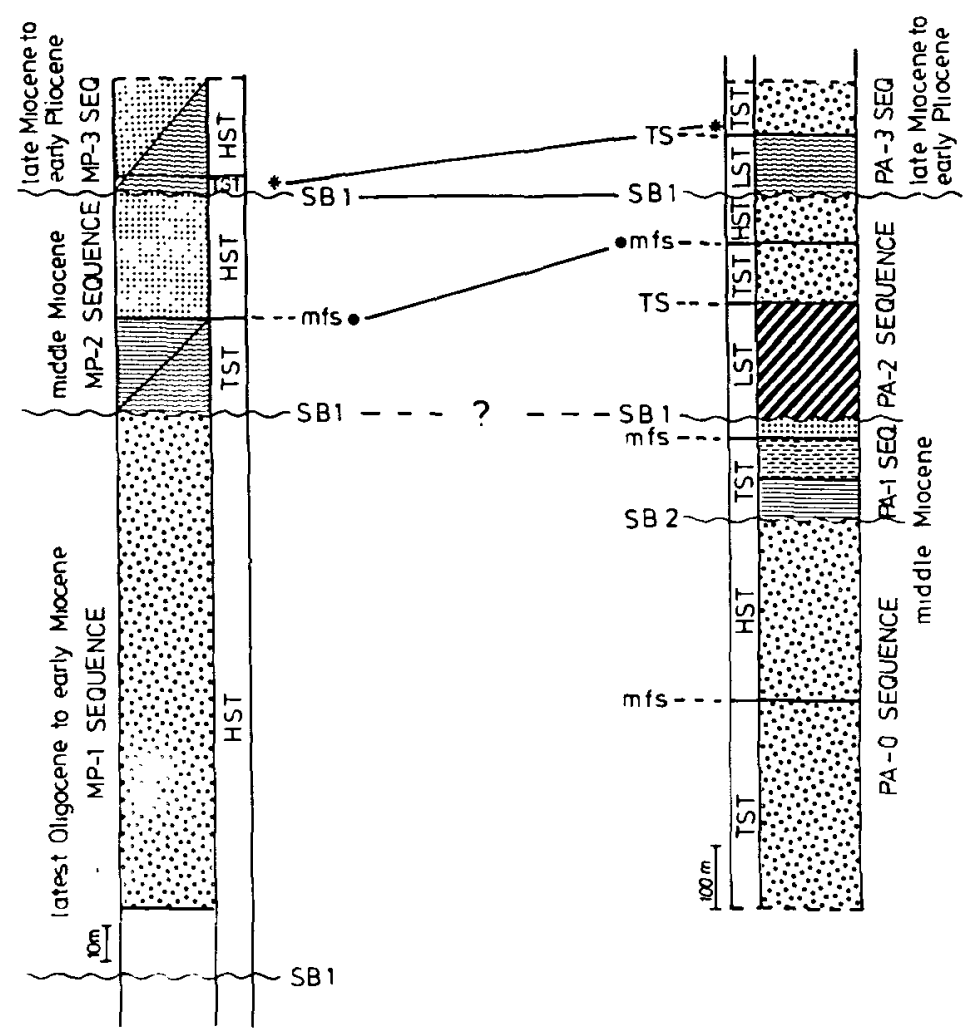

Shoreface
Shallow Shelt
Deeper Shelt
Delta Front
Amber Prodelta
Ambinoides Horizon

Fig. 7. Sequence-stratigraphic correlation between Malpaís Basin and Parrita Basin. Note the different scales and tumespans of each section. 
The correlation between MP- 2 and PA- 2 sequence boundaries is uncertain but seems probable with respect to sequence analysis. Correlation between MP-1 and PA-1 sequence boundaries is not possible. Age determination within the MP-1 sequence indicates a late Oligocene to early Miocene age, whereas planktonic Foraminifera of the basal part of the PA-1 sequence belong to zone N9 (early middle Miocene). This implies a hiatus associated with the MP-2 sequence boundary.

\section{CONCLUSIONS}

Taking into account the thickness of the shallowmarine successions (Malpaís Basin, c. $250 \mathrm{~m}$; Parrita Basin, c. $1300 \mathrm{~m}$ ), sequence development, sequencestratigraphic interpretation, and correlation, as well as biostratigraphic data and correlation with published global sea-level charts, the following conclusions can be made.

The sequence boundaries developed within the relatively thin late Oligocene to early Pliocene Malpaís succession most probably represent sequence boundaries of second-order cycles according to Haq et al. (1988). Sequence boundaries within the middle Miocene to early Pliocene(?) succession of the Parrita Basin in contrast are considered as sequence boundaries of third-order cycles according to Haq et al. (1988). A basin to basin correlation is reliable at the level of second-order sequence boundaries.

Comparison with the global sea-level charts of Haq et al. (1988) implies a possible correlation of the MP-3 and PA-3 sequence boundary with the TB2/TB3 sequence boundary, and a correlation of the MP-1 sequence boundary with the TA4/TB1 supercycle sequence boundary, and the MP-2 sequence boundary with the TB1/TB2 supercycle boundary. The PA-1 and PA-2 sequence boundaries seem to correlate with sequence boundaries of middle Miocene third-order cycles.

Sequence boundaries of second-order cycles coincide with angular unconformities, implying a controlling function of tectonic events to the formation of second-order sequence boundaries within the fore-arc setting of the southern Central American island-arc system.

The application of sequence-stratigraphic criteria for interpretation and correlation of basin dynamics turned out to be a useful tool for basin analysis, even in such an inhomogeneous tectonic realm as an island-arc system. The examples presented show that sequences with similar stratal patterns developed at the same time in widely varied coastal embayments. This suggests a globally effective control, such as eustatic sea-level change, on sedimentation and basin development at the level of systems tracts, third-order depositional sequences, and parasequences.

\section{ACKNOWLEDGEMENTS}

This study was benefited by a grant from the Nachwuchsforderungsgesetz (Berlin) for one of the authors ( $H$. Schmidt). The 'Deutsche Forschungsgemeinschaft' (DFG) provided financial support for field trips (Se 490/1-1, Se 490/1-2). The research in Costa Rica was supported through the close collaboration of RECOPE (national oil company of Costa Rica and the 'Escuela Centroamericana de Geología' (University of Costa Rica). S. Brown, R.H. Dott, Jr. and D.I.M. Macdonald reviewed the manuscript and made many helpful suggestions.

\section{REFERENCES}

Astorga. A. (1987) El Cretácico Supertor y el Paleógeno de la veruente Pacifica de Nicaragua meridional y Costa Rica septentrional origen, evolución y dinámica de las cuencas profundas relactonadas con el margen convergente de Centroamérica. Unpublished tesis de Licencratura, University of Costa Rica, San José. $250 \mathrm{pp}$.

astorga. A., Ffrnandez, J.A., Barboza, G . Campos, L., Obando, J , Aguilar. A. \& Obando, L.G. (1989) Cuencas Sedimentarias de Costa Rica: Evoluctón Potenttal de Hidrocarburos. Transactions of the Fourth Circum-Pacific Councl for Encrgy and Mincral Resources Conference. Abstr. Vol., San Josć (Costa Ruca). pp. $1-18$.

Baum, G.R. \& VAIL, P.R (1987) Sequence stratigraphy. allostratıgraphy, sotope stratigraphy and biostratigraphy - putting it all together in the Atlantic and Gulf Palcocenc. 8th Research Conference SEPM/G('S Innovative Biostratigrapluc Approaches to Sequence Analvsis New Exploration Opportumities, Houston. Texas, pp. 15-23.

Balmgartner, P.O., Mora, C . Butteri.in, J., Sigil.. J., Clacon, G.. Azr Ma. J. \& Bolrgols. J (1984) Sedimentología ! palcogeografía del Cretacico ! Cenozoco del Ittoral Pacifíco de Costa Rica Rev Geol Ain Central 1. $57-136$

Cilvo. C (1987) Las caltzas nertucas de la vertuente Pacifica del norte de Costa Rica, sur de Nicaragua epocas y sastemas de sedimentación asoctadas, con la apertura evolución del margen convergente de la América Central Meridional Unpublished tess de l.cenciatura. University of Costa Rica. San Jose. 16.5 pp 
Dengo, G. (1962) Estudio geologico de la regıón de Guanacaste, Costa Rica. Inst. Geogr. Nac., San José, $1 \mathrm{x}+112 \mathrm{pp}$.

Fischer, R. (1981) Dic Herausformung des mittelamerikanischen Isthmus im Miozan Costa Ricas. Zentral. Geol. Palaeontol. Teil / 3/4, 219-221.

Haq, B.U., Hardenbol, J. \& Vall, P.R. (1988) Mesozoic and Cenozoic chronostratigraphy and cycles of sca-level. In: Sea-level Changes: an Integrated Approach (Eds Wilgus, C.K., Hastings, B.S., Kendall, C.G.Sr.C., Posamentier, H.W., Ross, C.A. \& van Wagoner, J.C.). Soc. Econ. Paleontol. Mineral., Spec. Publ. 42, 71-108.

KIDWELL, S.M. (1984) Outcrop features and origin of basin margin unconformities in the Lower Cheasapeake Group (miocenc) Atlantic Coastal Plain. In: Interregional Unconformuties and Hydrocarbon Accumulation (Ed. Schlee, F.S.). Mem., Am. Assoc. Petrol. Geol. $36,37-58$.

Kuypers, E.P. (1979) Analısis sedimentológico de la Formación Punta Carballo (Mioceno), Costa Rica. Inst. Geogr. Nac., Informe Semest. julio-diciembre, 77-94.

LUNDBERG, N. (1982) Evolution of the slope landward of the Middle America Trench, Nicoya Peninsula, Costa Rica. In: Trench-Forearc Geology (Ed. Legget, J.K.). Geol. Soc. London, Spec. Publ. 10, 133-147.

Mora, R.C. (1985) Sedimentología y geomorphología del Sur de la Peninsula de Nicoya (Provincia de Puntarenas, Costa Rtca). Unpublished tesis de Licenciatura, University of Costa Rica, San José, 148 pp.

Posamentier, H.W. \& VAlL, P.R. (1988) Eustatic controls on clastic deposition, II - sequence and systems tract models. In: Sea-level Changes: an Integrated Approach (Eds Wilgus, C.K., Hastings, B.S., Kendall, C.G.St.C., Posamentier, H.W., Ross, C.A. \& van Wagoner, J.). Soc. Econ. Palcontol. Mineral., Spec. Publ. 42 , 125-154.

Posamentier, H.W., Jervey, M.T. \& Vall, P.R. (1988) Eustatic controls on clastic deposition, I - conceptual frameword. In: Sea-level Changes: an Integrated Approach (Eds Wilgus, C.K., Hastings, B.S., Kendall, C.G.St.C., Posamentier, H.W., Ross, C.A. \& van Wagoner, J.). Soc. Econ. Palcontol. Mineral., Spec. Publ. 42. 109-124.

ScHmidt, H. (1989) Sequenzstratigraphie des neogenen Inselbogen-Schelfes im 'Forearc'-Bereich Costa Ricas und Nicaraguas. Unpublished PhD dissertation, Technische Universitat Berlın, 250 pp.

Schmot-Effing, R. (1979) Alter und Genese des NicoyaKomplexes, einer ozeanischen Palaokruste (Oberjura bis Eozan) im sudlichen Mittelamerika. Geol. Rundsch $68(2), 467-494$

Seyfrito, H. (1986) Strukturgeschichte und Sedimentation an cinem konvergenten Plattenrand: Das Beispiel der sudlichen mittelamerikanischen Landbrucke. Berliner Geowiss. Abh., (A). Sonderbd. X. Geowiss. Latemamer. Koll. , 7-13.
Seyfried, H. \& Aguilar, T. (1984) Sedimentologie und Palaiookologie jungtertiairer Sandwatt-Ablagerungen Costa Ricas. Tagungsh. 9. Geowiss. Latemamer.-Koll., 156- 159 .

Seyfried, H. \& Sprechmann, P. (1985) Sedimentology and paleoecology of a perilittoral estuarine siliciclastic sequence from the Middle Miocene of Costa Rica (Central America). Abstracts, Sympostum of Modern and Ancient Clastic Tidal Deposts, Utrecht. pp. 116-119.

Seyfried, H., Sprechmann, P. \& Agullar, T. (1985) Sedimentología y paleoccología de un estuario del litoral Pacífico del Istmo Centroamericano Primordial (Mioceno Medio, Costa Rica). Rev. Geol. Am. Central $3,1-68$.

Seyfried, H., Astorga, A., Calvo, C. \& Laurito, C. (1987) Sequence response (cyclicity, bıstratinomy. ichnofacies) to subsidence, sea-level fluctuations, and exceptional events in Cenozoic fore-arc basins of southern Central America. 8th Research Conference SEPM/GCS (Innovative Biostratigraphic Approaches to Sequence Analysis: New Exploration Opportunuttes), Houston, TX. pp. 131-141.

Shanmugan, G. (1988) Origin, recognition, and importance of erosional unconformities in sedimentary basins. In: New Perspectives in Basın Analysis (Eds Kleinspehn, K.L. \& Paola, C.) pp. 83-108. Springer-Verlag. New York.

Sprechmann, P. (Ed.) (1984) Manual de Geología de Costa Rıca, 1: Estratigrafía. Editorial de la Universidad de Costa Rica, San José, 324 pp.

VAll, P.R., Mrtchum, R.M., JR., Todd, R.G., WIDmier. J.M., Thompson, S., III, Sangree, J.R., Dubb, J.N. \& Haslid, W.G. (1977) Seismic stratigraphy and global changes of sea-level (parts 1-6). In: Setsmec Stratigraphy - Applications to Hydrocarbon Exploration (Ed. Payton, C.E.). Mem. Am. Assoc. Petrol. Geol. 26 49-205.

VAll, P.R. \& Topd, G.R. (1981) North Sea Jurassic unconformities, chronostratugraphy and sea-level changes from seismic stratigraphy. In: Petroleum Geology of the Continental Shelf, Northwest Europe (Eds Cling, J.V. \& Hobson, C.D.) pp. 216-235. Instutute of Petroleum, London.

Van Wagoner, J.C., Posamentier, H.W., Mitchum, R.M., VAIL, P.R., SARG, J.F., LOUnT, T.S. \& HardenBol, J. (1988) An overview of the fundamentals of sequence stratigraphy and key definttions. In. Sealevel Changes: an Integrated Approach (Eds Wilgus, C.K., Hastings, B.S., Kendall, C.G.Sr.C., Posamentier, H.W. Ross, C.A. \& van Wagoner, J.). Soc. Econ Paleontol. Mineral., Spec. Publ. 42, 39-46.

Wildberg. H. (1984) Der Nicoya-Komplex. Costa Rica. Zentralamerika: Magmatismus und Genese cines polygenetischen Ophiolith-Komplexes. Muensterche Forsch. Geol. Palaeontol. 62, 1-123. 